\title{
The Exopolysaccharide of Xylella fastidiosa Is Essential for Biofilm Formation, Plant Virulence, and Vector Transmission
}

\author{
N. Killiny, ${ }^{1}$ R. Hernandez Martinez, ${ }^{2}$ C. Korsi Dumenyo, ${ }^{3}$ D. A. Cooksey, ${ }^{4}$ and R. P. P. Almeida ${ }^{5}$ \\ ${ }^{1}$ Department of Entomology and Nematology, Citrus Research and Education Center, University of Florida, IFAS, 700 \\ Experiment Station Road, Lake Alfred 33850, U.S.A.; ${ }^{2}$ Department of Microbiology, Center for Scientific Research and \\ Higher Education of Ensenada, Km. 107 Ctra. Tijuana-Ensenada, 22860 Ensenada, Baja California, Mexico; ${ }^{3}$ Department of \\ Agricultural and Environmental Science, Tennessee State University, Nashville 37209, U.S.A.; ${ }^{4}$ Department of Plant \\ Pathology and Microbiology, University of California, Riverside 92521, U.S.A.; ${ }^{5}$ Department of Environmental Science, \\ Policy, and Management, University of California, Berkeley 94720, U.S.A.
}

Submitted 5 September 2012. Accepted 5 May 2013.

Exopolysaccharides (EPS) synthesized by plant-pathogenic bacteria are generally essential for virulence. The role of EPS produced by the vector-transmitted bacterium Xylella fastidiosa was investigated by knocking out two genes implicated in the EPS biosynthesis, gumD and gumH. Mutant strains were affected in growth characteristics in vitro, including adhesion to surfaces and biofilm formation. In addition, different assays were used to demonstrate that the mutant strains produced significantly less EPS compared with the wild type. Furthermore, gas chromatography-mass spectrometry showed that both mutant strains did not produce oligosaccharides. Biologically, the mutants were deficient in movement within plants, resulting in an avirulent phenotype. Additionally, mutant strains were affected in transmission by insects: they were very poorly transmitted by and retained within vectors. The gene expression profile indicated upregulation of genes implicated in cell-to-cell signaling and adhesins while downregulation in genes was required for within-plant movement in EPSdeficient strains. These results suggest an essential role for EPS in $X$. fastidiosa interactions with both plants and insects.

Bacteria produce polysaccharides in their natural habitat or when cultured in vitro; polysaccharides may also be directly associated with the virulence of pathogens. Extracellular polysaccharides (EPS), which are secreted and may be loosely associated with cells as a capsule or released in the environment as slime, have various functions, including essential roles in biofilm formation and maintenance (Denny 1995). EPS is a major component of the extracellular polymeric substances surrounding cells in biofilms, which also include proteins, nucleic acids, and lipids. These components form a matrix responsible for biofilm stability (Flemming and Wingender 2010). Therefore, EPS is important for the development of biofilms and, in the case of pathogens where biofilm formation is

Corresponding author: N. Killiny; Telephone: +1.863.956.8833; Fax: +1.863.956.4631; E-mail: nabilkilliny@ufl.edu

This article is in the public domain and not copyrightable. It may be freely reprinted with customary crediting of the source. The American Phytopathological Society, 2013. important for the progression of infections, mutants deficient in EPS production are generally avirulent (Guo et al. 2010; Katzen et al. 1998).

In the case of plant-associated bacteria, biofilm formation has been shown to be essential for the development of mutualistic, commensal, and pathogenic host-microbe interactions (Danhorn and Fuqua 2007). EPS production, specifically, has been shown to be involved in successful colonization of epiphytic and vascular plant pathogens such as Erwinia amylovora (Koczan et al. 2009); in the case of epiphytes, EPS also prevents biofilm desiccation, thus increasing the fitness of bacterial populations (Rigano et al. 2007). Although it is difficult to determine whether EPS itself is responsible for virulence, because its absence may have pleiotropic effects, it is tightly connected to disease in vascular plant pathogens. Various vascular pathogens, such as Erwinia, Xanthomonas, and Clavibacter spp., produce EPS while colonizing plants, which leads to clogging of xylem vessels.

Xylella fastidiosa is a xylem-limited plant-pathogenic bacterium transmitted by xylem sap-feeding leafhopper vectors (Severin 1949). Cells inoculated into host plants by insect vectors develop into biofilms that eventually occlude sap flow through the plant, leading to water stress symptoms (Fry and Milholland 1990; Newman et al. 2003). Biofilms are also established within the mouthparts of insect vectors (Almeida and Purcell 2006). In both environments, it has been suggested that EPS secreted into vessels or the mouthparts of vectors allow for the development of biofilms (Almeida and Purcell 2006; Chatterjee et al. 2008). That contention is supported by the fact that $X$. fastidiosa has an operon with high homology to the Xanthomonas campestris gum operon (Simpson et al. 2000). Although various studies have indirectly analyzed Xylella fastidiosa gum genes and their expression patterns, little evidence exists on the role of the gum operon and the putative EPS it specifies. Souza and associates (2006) constructed two gum mutants using an isolate of $X$. fastidiosa subsp. pauca that causes disease in citrus, and found that biofilm formation was affected but the mutations had no effect on EPS production. Evidence that EPS is associated with $X$. fastidiosa subsp. fastidiosa infections of plants was obtained immunologically, with antibodies generated against a modified xanthan gum polymer expected to be similar to EPS of $X$. fastidiosa based on gum operon homology (Roper et al. 2007). More recently, evidence that EPS production is controlled by intracellular signal- 
ing was obtained (Chatterjee et al. 2010). Thus, although EPS is expected to be essential for plant and insect colonization in $X$. fastidiosa, there are no studies directly demonstrating that to be the case.

The gum operon in Xanthomonas campestris encodes the enzymes involved in biosynthesis of xanthan gum, a polysaccharide required for plant pathogenicity (Katzen et al. 1998; Vojnov et al. 2001) and also widely used in the food industry (Garcia-Ochoa et al. 2000). This operon has 12 genes in $X$. campestris; compared with X. campestris gum operon, Xylella fastidiosa lacks three genes, which are all involved in the addition and modification of the last mannose residue to the repeating oligosaccharide subunit in the polymer (Fig. 1) (da Silva et al. 2001; Katzen et al. 1998). Therefore, xanthan is a polymer composed of pentasaccharide units, whereas the EPS of X. fastidiosa is predicted to be composed of tetrasaccharide repeating units (da Silva et al. 2001; Katzen et al. 1998). In addition to the synthesis pathway and oligosaccharide composition, secretion of both polymers is also predicted to be similar. Briefly, after the oligosaccharides are assembled on a polyprenol phosphate carrier in the inner membrane and repeat units polymerized, they are likely secreted through polysaccharide-specific transport systems (da Silva et al. 2001; Ielpi et al. 1993; Katzen et al. 1998). The role of Gum proteins in xanthan synthesis has been well characterized (Katzen et al. 1998). Among those proteins, GumD initiates synthesis of the pentasaccharide by catalyzing the transfer of glucosyl-1-phospate to the polyprenol phosphate carrier anchored in the inner membrane; a gumD mutant did not produce any xanthan. GumH, which is also a glycosyltransferase, adds the third monomer in the chain (mannose); a gumH mutant produced an oligosaccharide but it was not polymerized.
Because of their role in Xanthomonas campestris EPS formation, GumD and GumH represent good candidates to determine the role of EPS production in Xylella fastidiosa. It can be predicted, assuming functional similarity of gum genes between these two bacteria, that a gumD mutant would not produce any EPS in $X$. fastidiosa while a gumH mutant would produce EPS lacking acetyl-D-mannose and D-glucuronic acid (glucan) residues. Mutants of both genes in X. fastidiosa were generated to test their role in EPS production, biofilm formation, plant virulence, and vector transmission. Results indicate that GumD and GumH are functionally similar to their Xanthomonas campestris homologs, and that EPS production affects all phenotypic aspects of the biology of Xylella fastidiosa tested here.

\section{RESULTS}

Disruption of gumD and gum $H$ affects cell growth, colony morphology, and aggregation.

The gumD and gumH genes of $X$. fastidiosa subsp. Fastidiosa isolate Temecula were disrupted (Fig. 1). In vitro tests showed that the wild-type strain reached higher densities in both media tested (periwinkle wilt medium [PW; Hill and Purcell 1995] and X. fastidiosa medium [XFM-pectin; Killiny and Almieda 2009a]) than either mutant, despite the fact that these media differ greatly in their chemical constituents (Fig. 2A). The gum mutants had similar growth regardless of media. Because optical density (OD) is a proxy for cell numbers, EPS may affect light absorbance, and clumping may be more common in mutants, it is possible that OD measurements are not ideal to robustly estimate cell numbers. On solid PWG medium (Hill and Purcell 1995), single colonies of the wild type were mor-
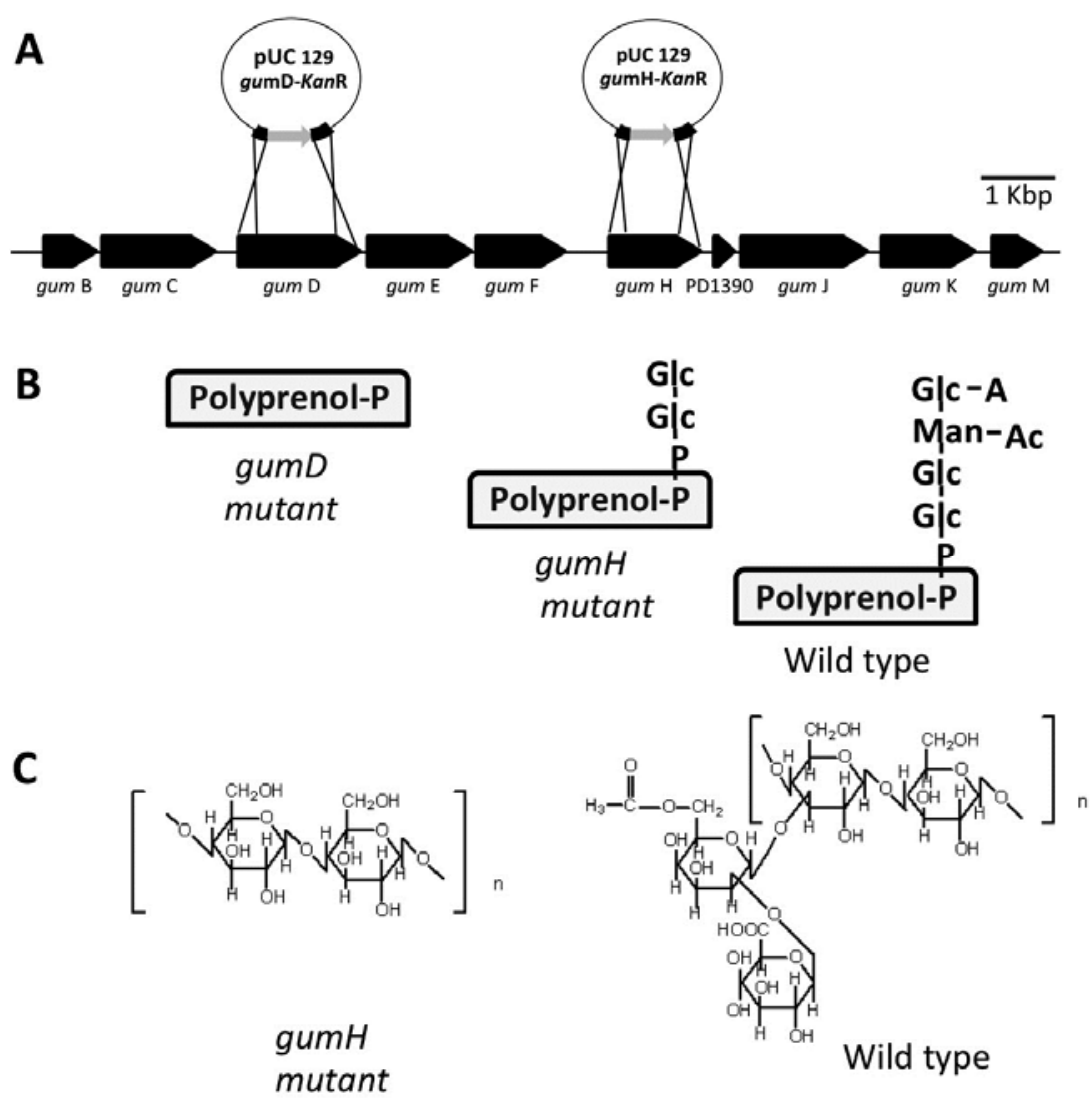

Fig. 1. A, Genetic map of the Xylella fastidiosa gum operon; plasmids and targeted genes for disruption are indicated. B, Repeating units in gum polymer expected from gumD and gumH mutants compared with the wild type, as added to the polyprenol. C, Putative exopolysaccharide structure expected for the gumH mutant compared with the wild type; gumD not shown because no additional residues are expected to be added to polyprenol. 
phologically typical, with minor satellites colonies (at approximately 10 days); whereas, in both gumD and gumH mutants, the colonies had a "flat" morphology and satellite colonies were not observed (Fig. 2B). Bacterial lawns grown on solid XFM-pectin and PWG were also compared (Fig. 2C and D). The wild type had a glossy and uniform appearance on XFMpectin compared with PWG, whereas the gumD and gumH mutants had a uniform but not glossy appearance in both media. These observations indicate that EPS is responsible for the glossy appearance of $X$. fastidiosa colonies in vitro. Attempts to complement both mutants were unsuccessful, because neither mutant survived electroporation with complementing plasmids or in control electroporation experiments with empty vectors or without any vectors.

\section{Mutants are deficient in biofilm formation.}

In static biofilm experiments, the gumD and gumH mutants were similar to each other and showed reduced surface adhesion compared with the wild type (Fig. 2E). The ratio of planktonic to attached cells in the dynamic biofilm assay indicated that the number of planktonic cells was similar among all treatments but, again, gumD and gumH mutants had reduced attachment to surfaces (Fig. 2F).

\section{GumD and GumH are required for EPS production.}

EPS was detected using the glucan-specific stain Alcian blue 8GX (Chatterjee et al. 2010); results showed that the wild type produced more EPS (heavily stained) compared with both mutants (Fig. 3A). We also used a quantitative immunological assay, based on antibodies previously shown to react with $X$. fastidiosa gum, to estimate EPS production. Results showed that the gumD and gumH mutants produced significantly less EPS than the wild type (Fig. 3B), as observed with the Alcian blue 8GX stain assay. Differences between the mutants and the wild type were significant $(P<0.001)$, as were the tested treatments (washed versus unwashed cells only for the wild type, $P<$ 0.001 ), and the interaction between strains and wash treatment $(P<0.001)$. However, no significant difference between the two mutants was observed.

Various $X$. fastidiosa cell surface proteins have been shown to affect cell adhesion. To test the role of EPS in cell-to-cell adhesion, cells grown in PWG medium were suspended and the turbidity of suspensions estimated over time. Both gumD and gumH mutants precipitated out of solution within $10 \mathrm{~min}$, whereas it took the wild type three times as long (Fig. 3C). Similar results were obtained when cells in the suspension were allowed to settle in vials, eventually precipitating (Fig. 3D). Our interpretation is that the absence of EPS results in additional cell-to-cell binding by exposed surface adhesins, resulting in the formation and eventual precipitation of large cell aggregates.

\section{gumD and gumH mutants}

do not produce oligosaccharide polymers.

One of the objectives of this study was to determine the sugar composition for the EPS extracted from $X$. fastidiosa wild-type and gum mutant strains. PW medium was used as a negative control. The only sugars identified in the media were fructose, mannose, and glucose, in addition to the disaccharides sucrose and trehalose (Fig. 4). EPS from the wild type was dominated by the presence of cellobiose $(\beta-1-4$ glucose
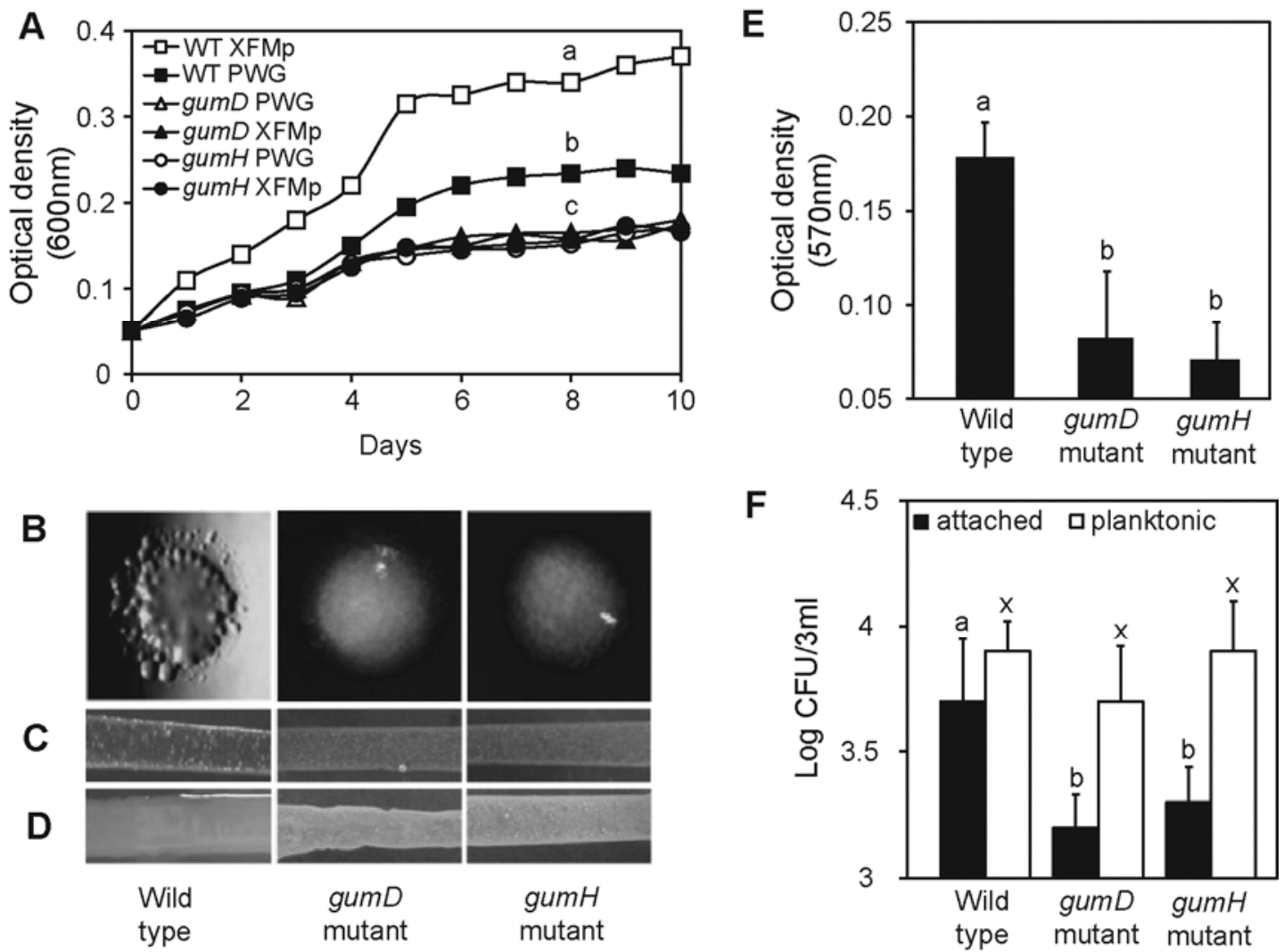

Fig. 2. Growth of Xylella fastidiosa mutant strains is affected in both liquid and solid media. A, Growth curve for various strains in periwinkle wilt medium (Hill andn Purcell 1995) (PW) and (X. fastidiosa medium [Killiny and Almeida 1009a] (XFM)-pectin liquid media (XFMp). B, Strains grown on PWG plates (Hill and Purcell 1995) for 10 days; colonies of gumD and gumH mutants had no satellite colonies compared with the wild type. C and D, Bacterial lawns on PWG and XFM-pectin media, respectively. Mutants had a sandy or dry appearance, compared with the glossiness of the wild type. E, Static biofilm formation on polystyrene surface (no shaking). F, Populations of planktonic versus glass-attached cells grown in vitro under shaking conditions (dynamic biofilm). Different letters indicate statistically different treatments. 
disaccharides) and oligosaccharides; the wide oligosaccharide peak represents the EPS polymer, which is predicted to have variable size. As expected, we did not find any specific carbohydrate produced by the gumD mutant. The gumH mutant produced only the disaccharide cellobiose, as was predicted based on its function in Xanthomonas campestris (Katzen et al. 1998). The lack of GumH probably resulted in the absence of linkage between the D-glucuronic acid and acetyl ester mannose residues, suggesting that polymerization occurs after the addition of these molecules. The results show that neither mutant produced EPS, explaining why they were phenotypically similar in all our bioassays.

\section{gumD and gumH mutants are not pathogenic}

to grapevines and are deficient in vector transmission.

In order to test the pathogenicity of gumD and gumH mutants, we mechanically inoculated grapevines with the wild type and the two mutants. Results showed that the mutants are avirulent and do not develop any symptoms compared with the wild type (Fig. 5A). To study the bacterial colonization and movement within plants, 16 weeks after inoculation, Xylella fastidiosa populations were estimated from the inoculation site and $50 \mathrm{~cm}$ above it by culturing cells from leaf petioles. In all, 12 individual plants were inoculated per treatment, and the number of $X$. fastidiosa positive plants was 12,4 , and 5 for the wild type, gumD, and gumH, respectively. No significant differences were found between the two points for the wild type. Both mutants were recovered from these sites but less frequently and with orders of magnitude lower populations (Fig. 5B). Furthermore, a significantly lower number of cells was

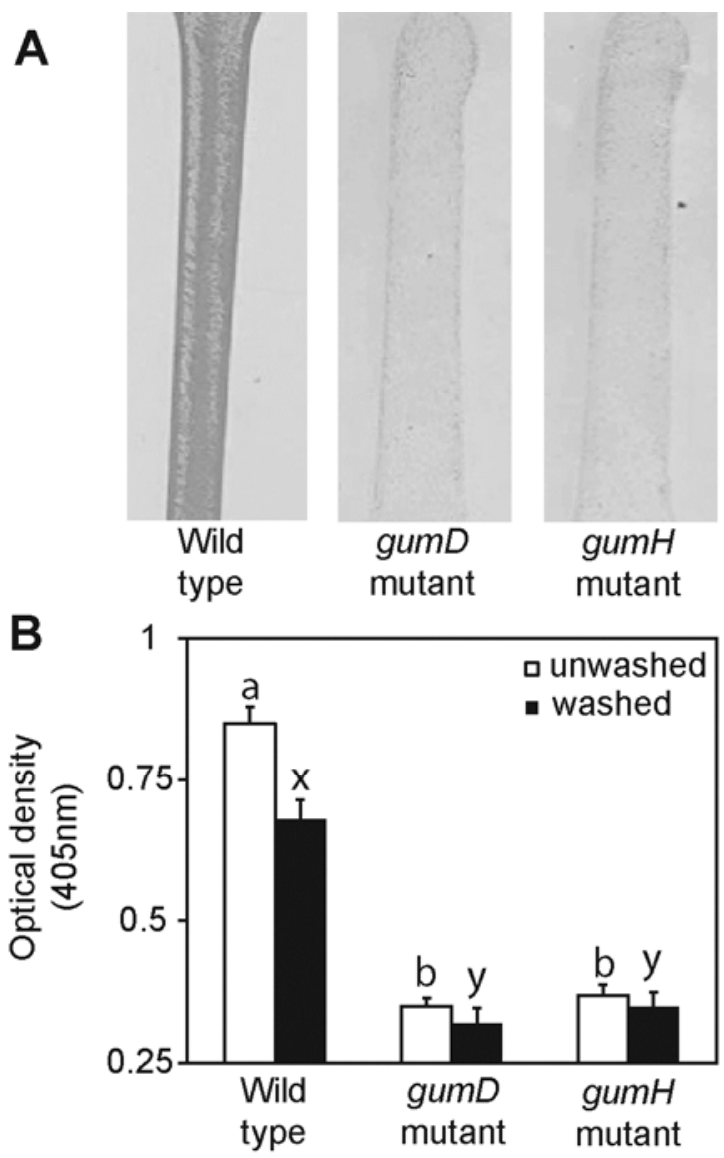

detected $50 \mathrm{~cm}$ above the inoculation site. Therefore, although the mutants were avirulent, they sustained very low populations that had limited movement within plants.

The transmissibility of the mutants was also tested with an efficient insect vector using two approaches: plant-to-plant transmission and an artificial diet system that delivers cells to insects directly. Results show that both mutants were poorly transmitted by vectors (Fig. 5C and D) and that they may not be retained over time (Fig. 5E). Plant-to-plant transmission resulted in no transmission of either mutant. Because these results could be a consequence of low X. fastidiosa populations in source plants, the artificial diet system was necessary to appropriately address questions associated with vector colonization. Both mutants were transmitted to plants when cells were delivered to vectors through an artificial diet, albeit inefficiently (Fig. 5D). This protocol enables the testing of mutants that are affected in colonization and movement within the plants. Finally, because gum mutants were deficient in plant colonization, the in vitro system was also used to determine inoculation efficiency into diets over time, after cells were acquired by vectors through the artificial feeding system. Inoculation of the wild type into artificial diets remained constant from 12 to $96 \mathrm{~h}$ post acquisition (Fig. 5E). Although inoculation of both gum mutant strains had similar efficiency immediately after acquisition, as was observed for inoculation into plants (Fig. 5D), no inoculation events were observed 72 and $96 \mathrm{~h}$ after acquisition. These results indicate that, over time, either gum mutants are lost from the foregut of vectors (i.e., not able to colonize) or the remaining cells were too strongly adhered to the cuticle, making detachment difficult.
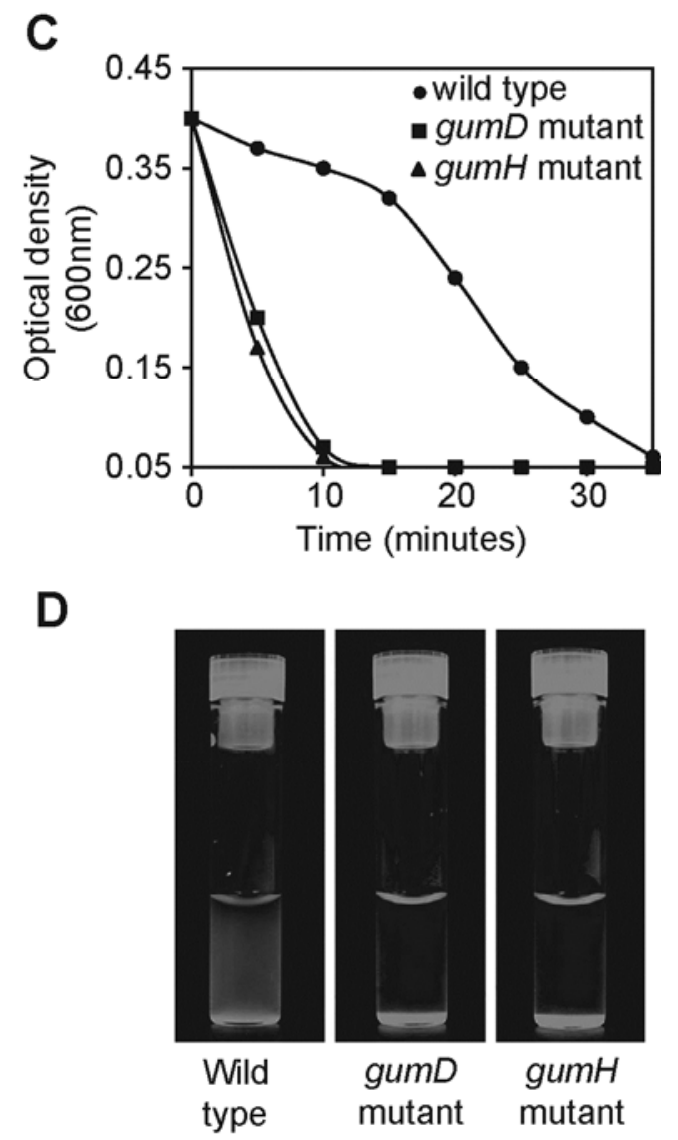

Fig. 3. Production of exopolysaccharide (EPS) and cell aggregation are affected in gum mutants. A, Pictures of the glucan-specific dye Alcian blue 8GX staining of cell lawns printed on nitrocellulose membrane. B, Quantification of EPS production; black and white columns indicate unwashed and washed cells, respectively; different letters indicate statistically different treatments. C, Sedimentation rate of cells suspended in buffer over time (static conditions). D, Photographs of static cell suspensions after $15 \mathrm{~min}$ without agitation. 
Gene expression is impacted in gum mutants.

Although EPS is a cell structural component, its absence is expected to affect the phenotype of $X$. fastidiosa, and gene expression patterns may be informative in describing such changes. Three groups of genes were assayed via quantitative reverse-transcription polymerase chain reaction (qRT-PCR): i) those involved in movement (type IV pili) and adhesion (fimbrial and afimbrial adhesins), ii) those involved in polysaccharide production and degradation, and iii) cell-to-cell signal production and transduction (Fig. 6). Genes implicated in bacterial movement within the plant (pil genes) were downregulated in the mutants, which matches the phenotype of the gum

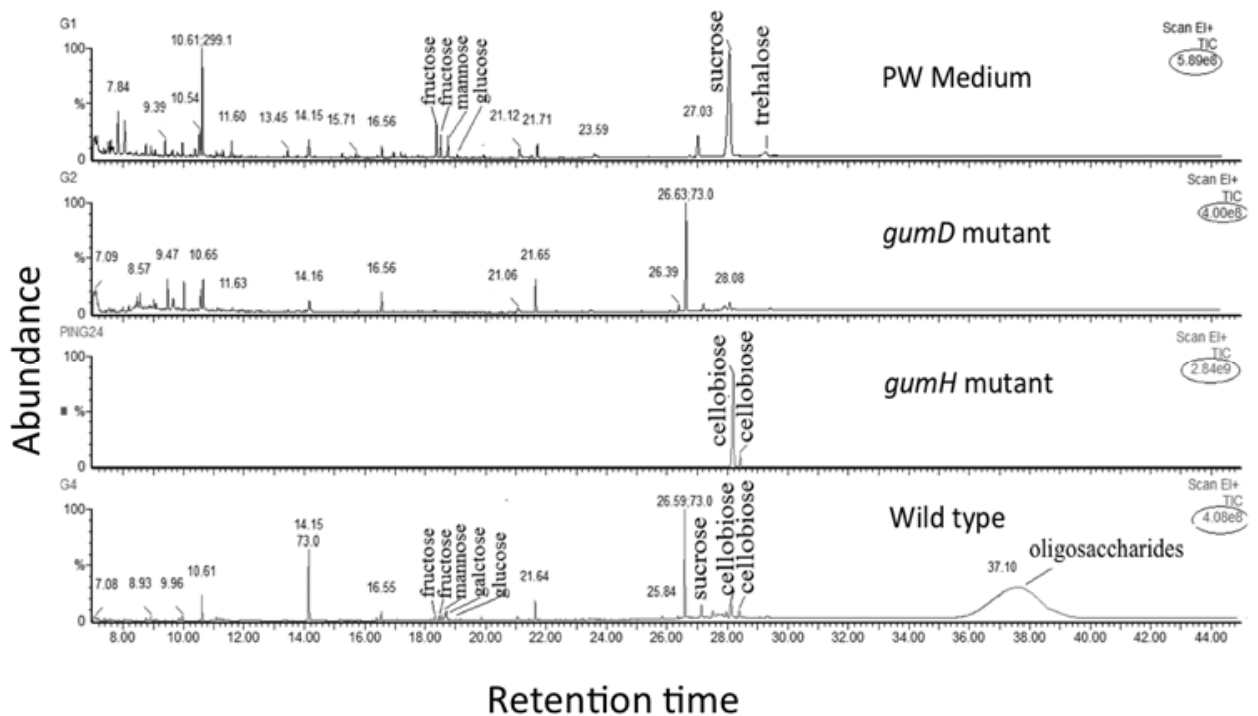

Fig. 4. Chromatograms representative of the carbohydrate contents in the exopolysaccharide (EPS) of Xylella fastidiosa strains. The gumH mutant was enriched for cellobiose, as expected, based on the predicted polymerization steps; the wild type had low concentrations of cellobiose, probably because polymerization was completed and oligosaccharides were produced (right side of chromatogram). Oligosaccharides were not observed for either mutant, which would explain the fact that both had the same phenotype in all bioassays performed, indicating no secretion of EPS in either case.
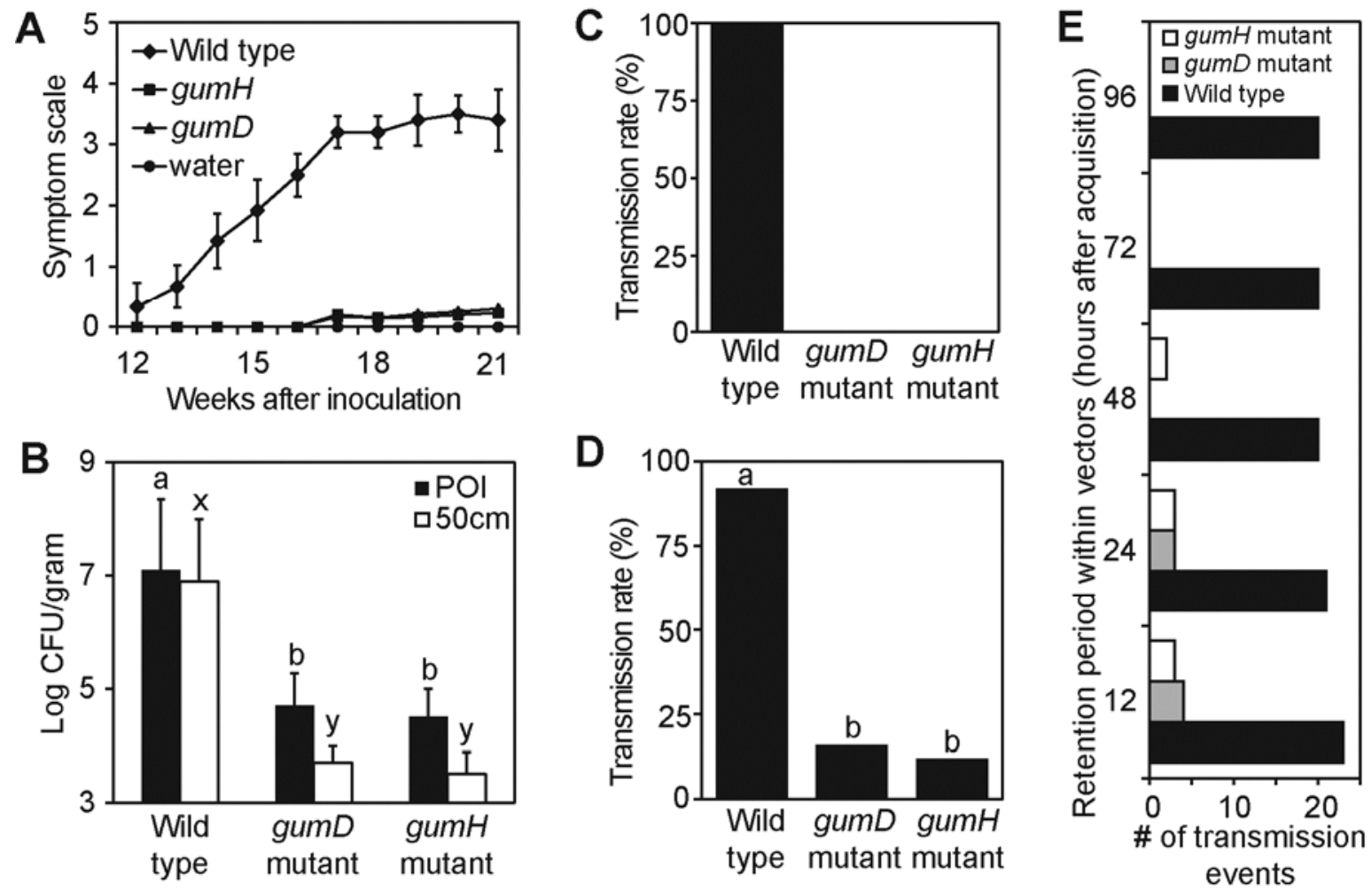

Fig. 5. gum Mutants are avirulent to plants and deficient in vector transmission. A, Symptom development in Xylella fastidiosa mechanically inoculated grapevines. B, Bacterial populations at the point of inoculation (POI) and $50 \mathrm{~cm}$ above that site 16 weeks after inoculation; average populations were determined using only positive plants. C, Vector transmission efficiency of strains from plant to plant. D, Vector transmission efficiency using an artificial diet system for acquisition (pathogen delivery to vectors) followed by inoculation into healthy grapevines. E, Retention of $X$. fastidiosa cells in insects; acquisition was done with artificial diet systems, followed by various periods on an alternative host, and later (over time) inoculation into artificial diet systems. Experiments measured the proportion of individuals inoculating cells into artificial diet systems; therefore, it is a composite estimation of retention within vectors and inoculation frequencies. 
mutants in plants. Although the in vitro biofilm assays showed that the mutants were deficient in biofilm formation, we found that genes implicated in attachment and biofilm formation were upregulated (fim, $h x f$, and $X a d A$ ). A chitinase (chiA) but not a polygalacturonase ( $p g l A)$ or endoglucanase (engxcA) had its transcription slightly affected in the mutants. Expression of other genes in the gum operon were not affected, suggesting that gum production is not controlled by its presence on the cell surface. Most of the genes involved in the cell-to-cell signaling system were upregulated in relation to the wild type. It is possible that EPS is involved in signal retention near the cell surface or facilitates signal binding to sensors; thus, its absence could result in overexpression of genes in this system.

\section{DISCUSSION}

Production of EPS is an important feature of many plantpathogenic bacteria, including vascular pathogens. Although genomic information has indicated that $X$. fastidiosa should produce EPS that is structurally similar to xanthan due to the high homology of its gum operon with that of Xanthomonas campestris (da Silva et al. 2001), the role of EPS and gum genes had not been demonstrated for Xylella fastidiosa. Souza and associates (2006) generated $X$. fastidiosa subsp. pauca gum mutants (gumB and gumF) but they did not find a detectable effect on EPS production, although in vitro biofilm formation was affected. EPS production has been demonstrated to be environment dependent, when it was showed to be produced at higher quantities in biofilms compared with planktonic cells, and that copper increased the amount of EPS in media (Rodrigues et al. 2008). Production of EPS was also shown to occur in vitro and in planta using an immunological approach (Roper et al. 2007). Altogether, these studies indicate that EPS is produced by X. fastidiosa, and that it has a role in biofilms in vitro. However, its role in plant virulence and insect transmission remained to be determined, as did the role of the gum operon in EPS production. We show that gumD and gumH are required for EPS production and plant and insect colonization.

The roles of gumD and gumH in EPS production appear to be similar in $X$. fastidiosa and Xanthomonas campestris. GumD (UMP-glucoseltransferase) in implicated in the first step of production of the EPS while GumH (GDP-mannosyltransferase) in responsible for adding a unit of mannose to the second glucose residue (da Silva et al. 2001; Katzen et al. 1998). Both mutants did not produce detectable EPS. These results strongly suggest that the sugar branches are important for polymerization. The biological characterization of the two mutants shows that they are phenotypically similar, supporting biochemical observations. These results corroborate inferences based on sequence data (da Silva et al. 2001) and the experimental characterization of gumH (Alves et al. 2011; Muniz et al. 2004). Thus, it was not surprising that both mutants were phenotypically identical for all assays we performed. All data obtained support the requirement of the gumD and gumH in EPS production. The expectation for the two independent mutants, that no EPS would be produced, was also supported by the experiments performed, assisting in the interpretation of the functional role of gumD and $g u m H$ in the absence of assays with complemented mutants.

The lack of detectable influence of gum genes in EPS production previously observed (Souza et al. 2006) may have been a consequence of experimental conditions used in that study. Rodrigues and associates (2008) showed that EPS production increased in the presence of an antimicrobial compound. Biofilm formation has also been shown to be promoted in the presence of copper (Fogaca et al. 2010). Two solid media were used here and, although no direct quantification of
EPS was performed, colonies were visually more mucoid in one medium than another, indicating that EPS regulation is environment-dependent. As previously reported, some EPS was found to be tightly bound to cells (Roper et al. 2007) and gum mutants were impacted in biofilm formation (Souza et al. 2006). However, colorimetric assays may not be ideal to study biofilm formation in this context, because cells may form microcolonies in the absence of EPS, and polysaccharides allow for dyes to be retained in the biofilm. Direct estimates of live cells showed that the number of planktonic $X$. fastidiosa in media was similar for the wild type and both gum mutants while the number of attached cells was lower. These results support the contention that EPS is important for $X$. fastidiosa biofilm formation and maturation. Although not directly addressed in this study, EPS may also be important for natural competency in $X$. fastidiosa (Kung and Almeida 2011), because cell surface structure is expected to be modified in the absence of polysaccharides. Plant colonization by gum mutants was severely affected. In addition to inciting no observable symptoms, gum mutants were recovered less than half as often as the wild type for the point of inoculation or $50 \mathrm{~cm}$ above that site. When recovered, bacterial populations were two to three orders of magnitude lower. These mutants were clearly affected in multiplication and movement within plants. Limited movement within plants is expected, even for mutants that are deficient in movement, due to naturally disrupted pit membranes in grapevines (Perez-Donoso et al. 2010). However, the role of EPS itself in pathogenicity is less clear. Disease symptoms caused by $X$. fastidiosa infections are thought to be the result of water stress due to limited xylem sap flow, a consequence of large cell populations producing EPS eventually clogging vessels (Chatterjee et al. 2008; Newman et al. 2003).

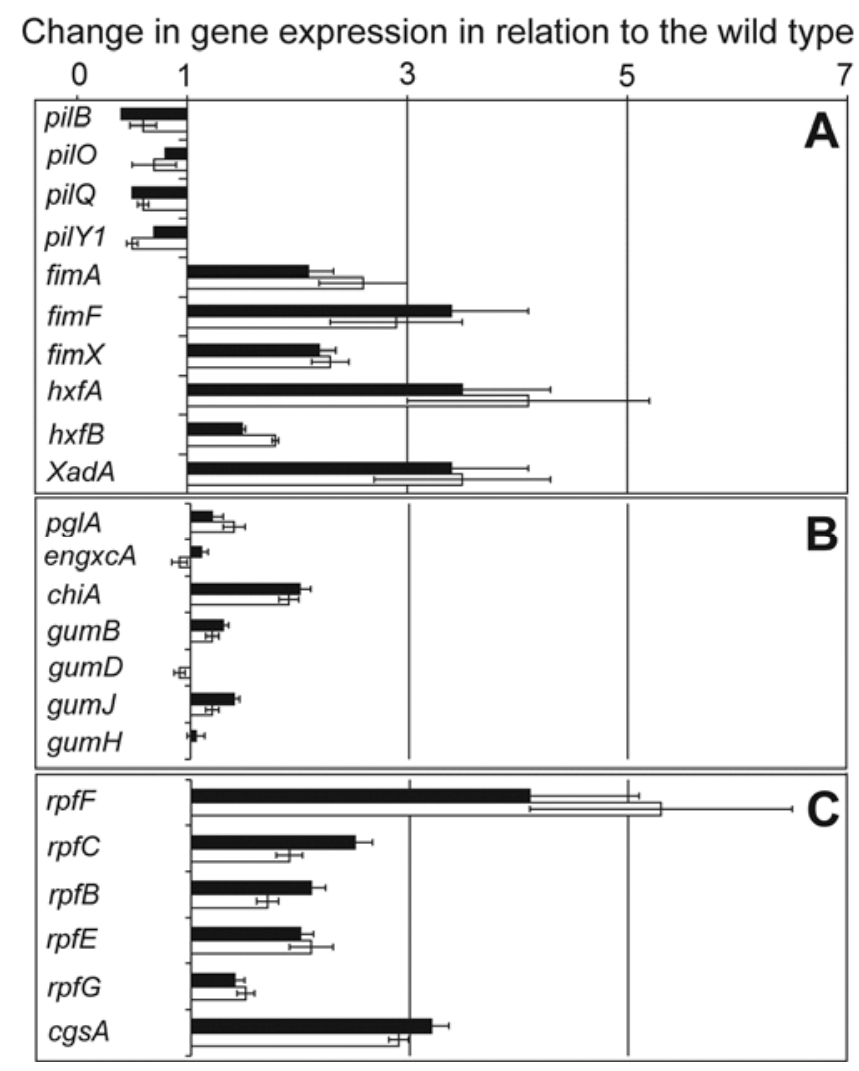

Fig. 6. Gene expression in gumD (black columns) and gumH (white columns) mutants is modified in relation to the wild type. A, Movement- and attachment-related genes. B, Genes associated with exopolysaccharide degradation and production. $\mathbf{C}$, Genes involved in inter- and intracellular signaling. Value of 1 indicates no difference in relation to the wild type. 
It is not clear if large populations result in clogging, if EPS produced during colonization reduces water flow, or if both act together to clog the xylem. The gum mutants never reached populations high enough to cause disease in grape and the importance of EPS itself in pathogenicity is not clear. This point was also brought up by Denny (1995), who suggested that gum mutants may be pleiotropic.

Three different experimental designs were used to test the role of EPS in vector transmission of X. fastidiosa; all led to the conclusion that EPS is required for dispersal of this pathogen. No transmission occurred with plant-to-plant transmission tests; this was not surprising, given that efficiency is correlated with bacterial populations in plants and gum mutants reached populations within plants at the minimum threshold for detectable transmission (Hill and Purcell 1997). When insects acquired $X$. fastidiosa from suspensions through an artificial diet, both mutants were transmitted to healthy plants, albeit at low efficiencies. When inoculation was performed into artificial diets instead of plants, similar results were obtained. These tests show that initial adhesion of gum mutants to vectors was diminished but still possible. However, colonization appeared to be impacted, because the proportion of individuals transmitting gum mutants decreased over time, with no detectable inoculation of cells into artificial diets 3 days after acquisition. It is possible, albeit improbable, that gum mutants successfully colonized the foregut for extended periods of time without being inoculated into diets. Finally, it is also possible that the few detectable transmission events were the result of nonspecific retention of cells in the foregut of vectors shortly after acquisition from artificial diets. Altogether, we conclude that EPS is important but not essential for cell adhesion to vectors; on the other hand, it appears to be essential for biofilm formation and maturation. Scanning electron microscopy of $X$. fastidiosa colonizing the cuticle of vectors indicates that EPS is important for vector colonization (Almeida and Purcell 2006). Finally, in natural conditions, it is possible that gum mutants are not capable of attaching to vectors; the artificial diet protocol delivers large populations of very sticky cells to insects (Killiny and Almeida 2009b), which probably does not happen with acquisition from infected plants.

Although EPS is not expected to directly regulate gene expression, the transcription of different gene categories was affected in the gum mutants. Most of transcriptional changes may be explained by the four- to fivefold overexpression of rpfF in the mutants. RpfF is involved in the synthesis of a cellto-cell signaling molecule (DSF) (Newman et al. 2004); accumulation of DSF in the environment is expected, among other things, to result in upregulation of fimbrial and afimbrial adhesins (fim, Hxf, and XadA genes) and downregulation of movement-associated pili (pil genes, part of type IV pilus system). The chitinase $c h i A$ was also previously shown to be under DSF regulation (Killiny et al. 2010). The gum genes, a polygalacturonase, and an endoglucanase were not differentially expressed in the mutants, while other regulatory genes were only slightly upregulated. As mentioned earlier, lack of EPS may affect unrelated aspects of cell physiology. In this case, it appears that upregulation of $r p f F$ is responsible for most changes in the transcriptional profile. It is possible that EPS serves as a DSF "accumulator" in the environment, so that this fatty acid would not diffuse so easily away from colonies. Lack of EPS may result in overproduction of DSF by cells if a minimum concentration of DSF in the environment is expected by the $r p f$ regulatory system. EPS has been shown to be a major component in the extra polymeric matrix that mediates adhesion and keeps extracellular enzymes close to cells, in addition to communication between cells in biofilms (Flemming and Wingender 2010; Flemming et al. 2007).
We showed that disruption of two genes in the gum operon impacts EPS production in X. fastidiosa, as predicted based on sequence homology with Xanthomonas campestris, in which the gum operon well is characterized. EPS production in Xylella fastidiosa is necessary for biofilm formation, plant virulence, and insect transmission. Unsuccessful attempts to complement both mutants precluded a complete characterization of gumD and gumH. However, the extensive biological assays performed, which corroborated predictions based on sequence homology, support their functional role in EPS production. Because of the essential role of EPS in the biology of $X$. fastidiosa, efforts to disrupt its production may result in alternative disease control strategies.

\section{MATERIALS AND METHODS}

\section{Bacterial strains.}

$X$. fastidiosa subsp. fastidiosa Temecula (van Sluys et al. 2003) was used as a wild type to generate the gumD and gumH knockout mutants, as described below. The strains were grown on the following media: PD3 (Davis et al. 1981), PWG (Hill and Purcell 1995), and XFM and XFM-pectin (Killiny and Almeida 2009b). Kanamycin at $10 \mu \mathrm{g} / \mathrm{ml}$ was added to the media for growing the knockout mutants.

\section{Construction of mutants and complementation attempts.}

Two genes in the $X$. fastidiosa gum operon, gumD and gumH, were disrupted by in vitro transposon mutagenesis of the $X$. fastidiosa gum operon cosmid, subcloning, and allelic exchange into the chromosome (Fig. 1). The genomic library of $X$. fastidiosa Temecula was constructed in the vector pCPP47 and the library was screened with gum-specific primers to identify the gum-positive clone. The cosmid was mutagenized in vitro with the Tn5 transposon using the EZ::TN $<$ KAN-2 $>$ insertion kit (Epicentre Technologies, Madison, WI, U.SA.) following the manufacturer's directions to disrupt the genes with a kanamycin cassette. The mutant clones were PCR screened for insertion into gumD (PD1394) and gumH (PD1391) using the primers gumD-p1 (5'-CTGCCGCTGATC TAATACTT-3') and gumD-P2 (5'-CTGATTGAGTGTGCCAA AG-3') for gumD, and gumH-P1 (5'-GGAGGATGTGGTCTT CAATA-3') and gumH-P2 (5'-GACTGTGACGGACTACAAT GA-3') for gum $H$. The transposon insertion was verified by PCR and sequencing. The same primers were used to amplify inactivated gumD and gumH, respectively, and amplicons were cloned into the SmaI site of the pUC129 vector. The inactivated gumD and gumH plasmids were transformed into electrocompetent $X$. fastidiosa cells, and transformants were selected on PD3 medium supplemented with kanamycin at 10 $\mu \mathrm{g} / \mathrm{ml}$. Marker exchange and the disruption of gumD and gumH on the chromosomes of mutants were confirmed by PCR and Southern blot (data not shown).

We unsuccessfully attempted to complement the gumD and GumH mutants, following the protocol described by Matsumoto and associates (2012). Briefly, gumD or gumH were amplified using the abovementioned primers and inserted into pCRBluntII-TOPO to generate pLBT-gumD and pLBT-gumH, respectively. The inserts with gumD or gumH were excised with SpeI and $X b a \mathrm{I}$ and, then, inserted into the $X b a \mathrm{I}$ site in plasmid pBBR1MCS-5 (Kovach et al. 1995). The resulting plasmids were electroporated into gumD and gumH mutants, respectively, and transformants were selected on PD3 medium supplemented with gentamicin at $10 \mu \mathrm{g} / \mathrm{ml}$. gumD and gumH mutants were also electroporated by themselves to determine whether the cells could grow after electroporation. In all cases, cells of the mutant strains were not viable following electroporation; therefore, transformation was unsuccessful. 
EPS production and quantification.

$X$. fastidiosa EPS production was quantified with specific protein-A double-antibody sandwich enzyme-linked immunosorbent assay (ELISA) and polyclonal antibodies against a modified xanthan gum polymer, which reacts with $X$. fastidi$o s a$ cells in vitro and in plants (Roper et al. 2007) (provided by Bruce Kirkpatrick, University of California, Davis). We also used the glucan-specific dye, Alcian blue 8GX (Sigma-Aldrich, St. Louis), to stain nitrocellulose membrane prints of $X$. fastidiosa colonies grown on PWG (Chatterjee et al. 2010).

\section{Biofilm formation assays.}

To study the static biofilm formation, X. fastidiosa cells were harvested from PWG plates and resuspended in liquid PW. Suspensions were adjusted to $10^{6}$ cells/ml (OD at $600 \mathrm{~nm}$ $\left[\mathrm{OD}_{600}\right]$ of approximately 0.1 ) and aliquots were loaded into 12 -well polystyrene culture plates. Plates were incubated for 2 days at $28^{\circ} \mathrm{C}$ without shaking. After incubation, we discarded the medium and planktonic and loosely attached cells were removed from the wells by washing plates with double-distilled water. Attached cells were stained the with $1 \%$ crystal violet for $10 \mathrm{~min}$ at room temperature. Excess of crystal violet was removed and wells were washed with double-distilled water. Crystal violet bound to the attached cells was solubilized with $1 \mathrm{ml}$ of $90 \%$ ethanol and quantified by measuring the absorbance at $570 \mathrm{~nm}$ (Chatterjee et al. 2008). We performed five biological replicates. Colony growth under shaking conditions were also used to study biofilm formation. We calculated the total number of attached and planktonic cells grown in liquid PW medium (Chatterjee et al. 2008; Killiny and Almeida 2009a). Briefly, 12 tubes of $3 \mathrm{ml}$ of PW medium for each strain were inoculated with $X$. fastidiosa cells with an initial $\mathrm{OD}_{600}$ of 0.05 . After 10 days of incubation at $28^{\circ} \mathrm{C}$ and shaking at $200 \mathrm{rpm}$, we estimated the number of live cells attached to walls and in the supernatant by dilution plating.

\section{Bacterial in vitro growth features.}

Growth curves were obtained for all strains grown in liquid PW and XFM-pectin media. We inoculated the media with $X$. fastidiosa cells collected from PWG plates 10 days after plating and adjusted the $\mathrm{OD}_{600}$ to 0.05 . Cultures were incubated at $28^{\circ} \mathrm{C}$ at $200 \mathrm{rpm}$ for up to 10 days. Daily samples from five independent replicates were taken for each strain-medium combination and vortexed, and the vial's $\mathrm{OD}_{600}$ was measured. We also investigated colony development and morphology using solid media (PWG and XFM-pectin) by placing 20- $\mu 1$ drops of suspensions, which were allowed to form stripes or spread evenly, with a glass rod so that individual colonies could be observed. Microscopy was performed with an epifluorescence stereomicroscope at the University of CaliforniaBerkeley Biological Imaging Facility.

\section{Sedimentation assay.}

Sedimentation speed was studied by collecting cells from PWG plates and suspending them in sterile distilled water to an $\mathrm{OD}_{600}$ of 0.4 . After vortexing, the tube's cell density was measured every $5 \mathrm{~min}$ at $\mathrm{OD}_{600}$ for $35 \mathrm{~min}$.

\section{Chromatography.}

Strains were grown in $100 \mathrm{ml}$ of PW medium with or without kanamycin for 10 days at $28^{\circ} \mathrm{C}$ and $160 \mathrm{rpm}$. The supernatant was collected by centrifugation followed by filtration with $0.22-\mu \mathrm{m}$ filters. The EPS were precipitated using ice-cold Ethanol and pellets resuspended in $1 \mathrm{ml}$ of MilliQ water. EPS derivatization was performed as described by Gullberg and associates (2004), with minor modifications. Briefly, 100- $\mu 1$ aliquots of the media, gumD mutant, and wild type extract, or
$10 \mu \mathrm{l}$ of gumH mutant extract, were dried under nitrogen stream. We used $10 \mu \mathrm{l}$ of gumH mutant extract because this mutant produced a huge amount of cellobiose and we needed to avoid the detector saturation. The dried gum was mixed with $30 \mu \mathrm{l}$ of methoxyamine hydrochloride solution in pyridine $(2 \%)$ and allowed to react for $17 \mathrm{~h}$ at room temperature. After methoximation, silylation reactions were induced by adding $80 \mu \mathrm{l}$ of $\mathrm{N}$-methyl-(N-trimethylsilyl) trifluoracetamide for $2 \mathrm{~h}$ at room temperature and $0.5 \mu \mathrm{l}$ of derivatized sample was injected into the gas chromatograph-mass spectrometer (GC-MS) running in the full scan mode.

Derivatized samples were analyzed using the Clarus 500 GC-MS system (Perkin Elmer, Waltham, MA, U.S.A.) fitted with an HP-5MS column (cross-linked 5\% Ph Me siloxane, 50 $\mathrm{m}$ by $0.22 \mathrm{~mm}$ by $0.025-\mu \mathrm{m}$ film thickness). The flow rate for the helium carrier gas was $0.7 \mathrm{ml} / \mathrm{min}$. The following GC temperature program was used: hold at $70^{\circ} \mathrm{C}$ for $5 \mathrm{~min}$, then increase to $180^{\circ} \mathrm{C}$ at a rate of $10^{\circ} \mathrm{C} / \mathrm{min}$, hold for $2 \mathrm{~min}$, increase further to $220^{\circ} \mathrm{C}$ at $10^{\circ} \mathrm{C} / \mathrm{min}$, hold for $2 \mathrm{~min}$, increase to $300^{\circ} \mathrm{C}$ at $10^{\circ} \mathrm{C} / \mathrm{min}$, and finally hold for $15 \mathrm{~min}$. The injector and the detector temperatures were 250 and $180^{\circ} \mathrm{C}$, respectively.

GC-MS chromatograms were analyzed using TurboMass software (version 5.4.2; Perkin Elmer). Peak identifications were achieved using the National Institute of Standards and Technology (Gaithersburg, MD, U.S.A.) and Wiley 9th edition (John Wiley and Sons, Inc., Hoboken, NJ U.S.A.) mass spectra database libraries.

\section{Virulence to plants.}

Strains were inoculated (approximately $10^{9} \mathrm{CFU} / \mathrm{ml}$ ) into grapevine (Vitis vinifera 'Cabernet Sauvignon') with 00 entomological pins by pricking (five times) a green stem tissue through a $20-\mu$ l suspension drop of the suspensions placed on the tissue (Hill and Purcell 1995). One site per plant was inoculated; each strain was inoculated into 12 plants. Symptoms were first evaluated 12 weeks after inoculation following the scale described by Guilhabert and Kirkpatrick (2005). We also estimated $X$. fastidiosa populations and its movement within the plants at 16 weeks post inoculation by culturing cells from the petiole of leaves immediately above inoculation site and 50 $\mathrm{cm}$ above the inoculation site (Hill and Purcell 1995).

\section{Vector transmission.}

We collected adults of blue green sharpshooter leafhoppers, Graphocephala atropunctata (Signoret) (Hemiptera: Cicadellidae), on riparian vegetation at the Russian river in Guerneville, CA. Insects were kept on sweet basil (Ocimum basilicum) and nymphs were transferred to healthy basil plants as needed. We used the second-generation adults to perform the transmission tests. General protocols for experiments were are previously published (Killiny and Almeida 2009b). Briefly, source grape plants were mechanically inoculated with either the wild type (Temecula) or one of the two mutants (gumD and gum H). After 3 months, $X$. fastidiosa cells were cultivated from inoculated plants to confirm infection status; we also used immunocapture PCR to confirm the results (Shapland et al. 2006). Two adult $G$. atropunctata were caged on each infected source plant for a 4-day pathogen acquisition access period. The insects were then transferred to healthy grape seedlings for a 4-day inoculation access period. Ten replicates were performed for each strain. Plants were maintained in the greenhouse for 3 months, after which $X$. fastidiosa cells were cultivated from leaf petioles to estimate the transmission rate.

We also used an artificial diet system to deliver transmissible cells to insect vectors (Killiny et al. 2012); this protocol is ideal for mutant strains that are poor plant colonizers, because 
bacterial populations within plants are correlated to acquisition and subsequent inoculation efficiency (Hill and Purcell 1997). Cells grown on XFM-pectin medium were suspended in a diet solution and made available to insects between two stretched layers of parafilm. After a 6-h acquisition access period at room temperature, insects were transferred to healthy plants for a 4-day inoculation access period. We performed 25 replicates for each treatment. The transmission rates were estimated as described above.

Despite the advantages of this protocol, it is still possible that some successful inoculation events are not detected if the mutant strain is not capable of multiplying or moving within its host plant. Therefore, we also performed a follow-up experiment in which insects were allowed to inoculate into an artificial diet instead of plants. After a 6-h acquisition access period, leafhoppers were transferred to sweet basil for up to 96 $\mathrm{h}$; at different time points, insects were removed from basil and transferred to $X$. fastidiosa-free artificial diets for a 5-h inoculation access period. The feeding period on basil allowed for cells to colonize vectors. The experimental design permitted combined inference on patterns of vector colonization and inoculation over time for the two mutants in relation to the wild type. Twenty-five replicates were performed (five treatments, 12 to $96 \mathrm{~h}$ ); cells were detected in diet using PCR (Rashed et al. 2011).

\section{Gene expression quantification.}

qRT-PCR was used to estimate the expression level of a different group of genes in the wild type and gumD and gumH mutants. Those included genes implicated in cell-to-cell signaling, carbohydrate degradation, cell movement, fimbrial and afimbrial adhesion, and EPS synthesis. RNA isolation, cDNA synthesis, and qPCR were performed as previously described (Chatterjee et al. 2008). Three biological replicates were used for each sample and three runs were performed for each replicate. The 16S rRNA gene was used as an internal control for normalization among samples.

\section{Statistical analyses.}

For ELISA quantification of EPS, static and dynamic biofilm formation, bacterial movement within plant, and bacterial growth curves, we used analysis of variance followed by a post hoc test (Tukey's test, $\alpha=0.05$ ). For the insect transmission tests, we used a one to three contingency-table analysis followed by pairwise comparisons using Fisher's exact test $(\alpha=0.05)$ with Bonferroni's correction to count multiple comparisons.

\section{ACKNOWLEDGMENTS}

We thank S. Lindow and A. Purcell for helpful discussions. This work was funded by the California Department of Food and Agriculture Pierce's Disease Research Program.

\section{LITERATURE CITED}

Almeida, R. P. P., and Purcell, A. H. 2006. Patterns of Xylella fastidiosa colonization on the precibarium of sharpshooter vectors relative to transmission to plants. Ann. Entomol. Soc. Am. 99:884-890.

Alves, C. A., Pedroso, M. M., de Moraes M. C., Souza, D. H., Cass, Q. B., and Faria, R. C. 2011. Real-time investigation of mannosyltransferase function of a Xylella fastidiosa recombinant GumH protein using QCM-D. Biochem. Biophys. Res. Commun. 408:571-575.

Chatterjee, S., Newman, K. L., and Lindow S. E. 2008. Cell-to-cell signaling in Xylella fastidiosa suppresses movement and xylem vessel colonization in grape. Mol. Plant-Microbe Interact. 21:1309-1315.

Chatterjee, S., Killiny, N., Almeida, R. P. P., and Lindow, S. E. 2010. Role of cyclic diGMP in Xylella fastidiosa biofilm formation, plant virulence and insect transmission. Mol. Plant-Microbe Interact. 23:13561363.
Danhorn, T., and Fuqua, C. 2007. Biofilm formation by plant-associated bacteria. Annu. Rev. Microbiol. 61:401-422.

da Silva, F. R., Vettore, A. L., Kemper, E. L., Leite, A., and Arruda, P. 2001. Fastidian gum: The Xylella fastidiosa exopolysaccharide possibly involved in bacterial pathogenicity. FEMS (Fed. Eur. Microbiol. Soc.) Microbiol. Lett. 203:165-171.

Davis, M. J., French, W. J., and Schaad, N. W. 1981. Axenic culture of the bacteria associated with phony disease of peach and plum leaf scald. Curr. Microbiol. 6:309-314.

Denny, T. P. 1995. Involvement of bacterial polysaccharides in plant pathogenesis. Annu. Rev. Phytopathol. 33:173-197.

Flemming, H. C., and Wingender, J. 2010. The biofilm matrix. Nat. Rev. Microbiol. 8:623-633.

Flemming, H. C., Neu, T. R., and Wozniak, D. J. 2007. The EPS matrix: The house of biofilm cells. J. Bacteriol. 189:7945-7947.

Fogaça, A. C., Zaini, P. A., Wulff, N. A., da Silva, P. I., Fázio, M. A., Miranda, A., Daffre, S., and da Silva, A. M. 2010. Effects of the antimicrobial peptide gomesin on the global gene expression profile, virulence and biofilm formation of Xylella fastidiosa. FEMS (Fed. Eur. Microbiol. Soc.) Microbiol. Lett. 306:152-159.

Fry, S. M., and Milholland, R. D. 1990. Multiplication and translocation of Xylella fastidiosa in petioles and stems of grapevine resistant, tolerant, and susceptible to Pierce's disease. Phytopathology 80:61-65.

García-Ochoa, F., Santos, V. E., Casas, J. A., and Gómez, E. 2000. Xanthan gum: Production, recovery, and properties. Biotechnol. Adv. 18:549-579.

Guilhabert, M. R., and Kirkpatrick, B. C. 2005. Identification of Xylella fastidiosa antivirulence genes: Hemagglutinin adhesins contribute to $X$. fastidiosa biofilm maturation and colonization and attenuate virulence. Mol. Plant-Microbe Interact. 18:856-868.

Gullberg, J., Jonsson, P., Nordstrom, A., Sjostrom, M., and Moritz, T. 2004. Design of experiments: An efficient strategy to identify factors influencing extraction and derivatization of Arabidopsis thaliana samples in metabolomic studies with gas chromatography/mass spectrometry. Anal. Biochem. 331:283-295.

Guo, Y., Sagaram, U. S., Kim, J. S., and Wang, N. 2010. Requirement of the galU gene for polysaccharide production by and pathogenicity and growth in planta of Xanthomonas citri subsp. citri. Appl. Environ. Microbiol. 76:2234-2242.

Hill, B. L., and Purcell, A. H. 1995. Multiplication and movement of Xylella fastidiosa within grapevine and four other plants. Phytopathology 85:1368-1372.

Hill, B. L., and Purcell, A. H. 1997. Populations of Xylella fastidiosa in plants required for transmission by an efficient vector. Phytopathology 87:1197-1201.

Ielpi, L., Couso, R. O., and Danjert, M. A., 1993. Sequential assembly and polymerization of the polyprenol-linked pentasaccharide repeating unit of the xanthan polysaccharide in Xanthomonas campestris. J. Bacteriol. 175:2490-2500.

Katzen, F., Ferreiro, D. U., Oddo, C. G., Ielmini, M. V., Becker, A., Pühler, A., and Ielpi L. 1998. Xanthomonas campestris pv. campestris gum mutants: Effects on xanthan biosynthesis and plant virulence. J. Bacteriol. 180:1607-1617.

Killiny, N., and Almeida, R. P. P. 2009a. Host structural carbohydrate induces vector transmission of a bacterial plant pathogen. Proc. Natl. Acad. Sci. U.S.A. 106:22416-22420.

Killiny, N., and Almeida, R. P. P. 2009b. Xylella fastidiosa afimbrial adhesins mediate cell transmission to plants by leafhopper vectors. Appl. Environ. Microbiol. 75:521-528.

Killiny, N., Prado, S. S., and Almeida, R. P. P. 2010. Chitin utilization by the insect-transmitted bacterium Xylella fastidiosa. Appl. Environ. Microbiol. 76:6134-6140.

Killiny, N., Rashed, A., and Almeida, R. P. P. 2012. Disrupting the transmission of a vector-borne plant pathogen. Appl. Environ. Microbiol. 78:638-643.

Koczan, J. M., McGrath, M. J., Zhao, Y., and Sundin, G. W. 2009. Contribution of Erwinia amylovora exopolysaccharides amylovoran and levan to biofilm formation: Implications in pathogenicity. Phytopathology 99:1237-1244.

Kovach, M. E., P. H. Elzer, D. S. Hill, G. T. Robertson, M. A. Farris, R. M. I. Roop, and K. M. Peterson. 1995. Four new derivatives of the broadhost-range cloning vector pBBR1MCS, carrying different antibioticresistance cassettes. Gene 166:175-176.

Kung, S. H., and Almeida, R. P. P. 2011. Natural competence and recombination in the plant pathogen Xylella fastidiosa. Appl. Environ. Microbiol. 77:5278-5284.

Matsumoto, A., Huston, S. L., Killiny, N, and Igo, M. M. 2012. XatA, an AT-1 autotransporter important for the virulence of Xylella fastidiosa Temecula 1. Microbiology open 1:33-45.

Muniz, J. R., Alves, C. A., de Pieri, C., Beltramini, L. M., Selistre-de- 
Araújo, H. S., Vettore, A. L., da Silva, F. R., Arruda, P., Garratt, R. C., Oliva, G., and Souza, D. H. 2004. Overexpression, purification, biochemical characterization, and molecular modeling of recombinant GDP-mannosyltransferase (GumH) from Xylella fastidiosa. Biochem. Biophys. Res. Commun. 315:485-492.

Newman, K. L., Almeida, R. P. P., Purcell, A. H., and Lindow, S. E. 2003. Use of a green fluorescent strain for analysis of Xylella fastidiosa colonization of Vitis vinifera. Appl. Environ. Microbiol. 69:7319-7327.

Newman, K. L., Almeida, R. P. P., Purcell, A. H., and Lindow, S. E. 2004 Cell-cell signaling controls Xylella fastidiosa interactions with both insects and plants. Proc. Natl. Acad. Sci. U.S.A. 101:1737-1742.

Pérez-Donoso, A. G., Sun, Q., Roper, M. C., Greve, L. C., Kirkpatrick, B., and Labavitch, J. M. 2010. Cell wall-degrading enzymes enlarge the pore size of intervessel pit membranes in healthy and Xylella fastidiosainfected grapevines. Plant Physiol. 152:1748-1759.

Rashed, A., Killiny, N., Kwan, J., and Almeida, R. P. P. 2011. Background matching behaviour and pathogen acquisition: Plant site preference does not predict bacterial acquisition efficiency by vectors. ArthropodPlant Interact. 5:97-106.

Rigano, L. A., Siciliano, F., Enrique, R., Sendín, L., Filippone, P., Torres, P. S., Qüesta, J., Dow, J. M., Castagnaro, A. P., Vojnov, A. A., and Marano, M. R. 2007. Biofilm formation, epiphytic fitness, and canker development in Xanthomonas axonopodis pv. citri. Mol. Plant-Microbe Interact. 20:1222-1230.

Rodrigues, C. M., Takita, M. A., Coletta-Filho, H. D., Olivato, J. C., Caserta, R., Machado, M. A., and de Souza, A. A. 2008. Copper resistance of biofilm cells of the plant pathogen Xylella fastidiosa. Appl. Microbiol. Biotechnol. 77:1145-1157.

Roper, M. C., Greve, L. C., Labavitch, J. M., and Kirkpatrick, B. C. 2007. Detection and visualization of an exopolysaccaride produced by Xylella fastidiosa in vitro and in planta. Appl. Environ. Microbiol. 73:72527258.

Severin, H. H. P. 1949. Transmission of the virus of Pierce's disease of grapevines by leafhoppers. Hilgardia 19:190-206.

Shapland, E. B., Daane, K. M., Yokota, G, Y., Wistrom, C., Connell, J. H., Duncan, R. A., and Viveros, M. A. 2006. Ground vegetation survey for Xylella fastidiosa in California almond orchards. Plant Dis. 90:905-909.

Simpson, A. J. G., Relnach, F., Arruda, P., Abreu, F. A., Acencio, M. Alvarenga, R., Alves, L. M., Araya, J. E., Bala, G. S., Baptista, C. S., Barros, M. H., Bonaccorsl, E. D., Bordin, S., Bove, J. M., Briones, M. R. S., Bueno, M. R. P., Camargo, A. A., Camargo, L. E., Carraro, D. M., Carrer, H., Celauto, N. B., Colombo, C., Costa, F. F., Costa, M. C. R., Costa-Neto, C. M., Coutinho, L. L., Cristofani, M., Dias-Neto, H.,
Doceno, C., El Dorry, H., Ferretra, A. J. S., Ferretra, V. C., Ferro, J. A., Fraga, J. S., Franca, C., France, M. C., Frohme, M., Urlan, L. R., Carnler, M., Goldman, G. H., Gomes, S. L., Gruber, A., Ho, P. L., Hoheihel, J. D., Junqueira, M. L., Kemper, E. L., Kitajima, J. P., Krieger, J. E., Kuramae, E. E., Lalgret, F., Lambals, M. H., Leite, L. C. C., Lemos, E. G. M., Lemos, M. V. F., Lopes, S. A., Lopes, C. R., Machado, J. A., Machado, M., Maderia, A. M. B. N., Maderia, H. M. F., Marine, C. L., Marques, M. V., Martins, E. A. L., Martins, E. M. F. Matsukuma, A. Y., Menck, C. F. M., Miracca, E. C., Miyaki, C. Y., Monteiro-Vitorelle, C. B., Moon, D. H., Nagai, M. A., Nascimento, A. L. T. O., Notto, L. E., Nhani, A., Jr., Nobrega, F. G., Nunes, L. R., Oliveira, M. A., Oliveira, M. C., De Oliveira, R., Palmeiri, D., Paris, A., Elxoto, B. R., Pereira, G. A. G., Pereira H. A., Jr., Pesquero, J. B. Quaggio, R., Roberto, P. G., Rodrigues, V., Rosa, A. J. D. M., De Rosa A. J., Jr., De Sa, R. G., Santelli, R., Sawaki, H. E., Da Silva, A. C., Da Silva, A. M., Da Silva, F. R., Silva, W. A., Jr., and Da Silveira, J. F. 2000. The genome sequence of the plant pathogen Xylella fastidiosa: The Xylella fastidiosa consortium of the organization for nucleotide sequencing and analysis, Sao Paulo, Brazil. Nature 406:151-157.

Souza, L. C., Wulff, N. A., Gaurivaud, P., Mariano, A. G., Virgílio, A. C. Azevedo, J. L., and Monteiro, P. B. 2006. Disruption of Xylella fastidiosa CVC gumB and gumF genes affects biofilm formation without a detectable influence on exopolysaccharide production. FEMS (Fed. Eur. Microbiol. Soc.) Microbiol. Lett. 257:236-242.

Van Sluys, M. A., de Oliveira, M. C., Monteiro-Vitorello, C. B., Miyaki, C. Y., Furlan, L. R., Camargo, L. E., da Silva, A. C., Moon, D. H., Takita, M. A., Lemos, E. G., Machado, M. A., Ferro, M. I., da Silva, F. R., Goldman, M. H., Goldman, G. H., Lemos, M. V., El-Dorry, H., Tsai, S. M., Carrer, H., Carraro, D. M., de Oliveira, R. C., Nunes, L. R., Siqueira, W. J., Coutinho, L. L., Kimura, E. T., Ferro, E. S., Harakava, R., Kuramae, E. E., Marino, C. L., Giglioti, E., Abreu, I. L., Alves, L. M., do Amaral, A. M., Baia, G. S., Blanco, S. R., Brito, M. S., Cannavan, F. S., Celestino, A. V., da Cunha, A. F., Fenille, R. C., Ferro, J. A., Formighieri, E. F., Kishi, L. T., Leoni, S. G., Oliveira, A. R., Rosa, V. E., Jr., Sassaki, F. T., Sena, J.A., de Souza, A. A., Truffi, D., Tsukumo, F., Yanai, G. M., Zaros, L. G., Civerolo, E. L., Simpson, A. J., Almeida, N. F., Jr., and Setubal, J. C. 2003. Comparative analysis of the complete genome sequences of Pierce's disease and citrus variegated chlorosis strain of Xylella fastidiosa. J. Bacteriol. 185:1018-1026.

Vojnov, A. A., Slater, H., Daniels, M. J., and Dow, J. M. 2001. Expression of the gum operon directing xanthan biosynthesis in Xanthomonas campestris and its regulation in planta. Mol. Plant-Microbe Interact. 14:768-774. 